\title{
A NARRATIVE REVIEW OF ZINGIBERACEAE FAMILY AS ANTIBACTERIAL AGENT FOR TRADITIONAL MEDICATION BASED ON BALINESE LOCAL WISDOM
}

\author{
Ni Made Ayu Irayanti ${ }^{1}$, A.A Gede Rai Yadnya-Putra ${ }^{{ }^{*}}$ \\ ${ }^{1}$ Departement of Pharmacy, Faculty of Math and Science, Udayana University, Bali, \\ Indonesia
}

Corresponding author email: agungryp@unud.ac.id

\begin{abstract}
Background: One of the native plants from Indonesia that have been widely used for traditional medication as an antibacterial comes from the Zingiberaceae family. Based on Usada Bali, the Zingiberaceae family used to treat digestive, respiratory, and skin diseases. Objective: This literature review aimed to discuss antibacterial activity from the Zingiberaceae family and see its validity as a traditional use as antibacterial based on Balinese local wisdom medication method (Usada) with its scientific evidence. Methods: The method of this literature review is the study of literature from several scientific publications in national and international journals about the antibacterial activity of the Zingiberaceae family. Results: Several studies showed that the Zingiberaceae family has an antibacterial activity with various inhibitions depended on the type of bacteria. Conclusion: The Zingiberaceae family mentioned in Usada Bali has been scientifically proved to have antibacterial activity, so it shows the validity as a traditional use as antibacterial based on Usada with its scientific evidence.
\end{abstract}

Keywords: Zingiberaceae, antibacterial, Usada

\section{INTRODUCTION}

Indonesian society is synonymous with local wisdom. Local wisdom is the result of certain societies based on their experiences that are not necessarily experienced by other societies. It may be called a cultural characteristic $^{[1]}$. There is a lot of local knowledge about health such as medicines inherited by society from ancestors which recorded on the manuscript. Some tribes in Indonesia still maintain their traditional medication knowledge until this present. Balinese is one of those tribes which has a traditional medication method called Usada, the manuscript of traditional Balinese treatment that contains various methods of medication and ceremony in self-purification and written on papyrus with the Balinese language and script ${ }^{[2]}$.
Various types of plants used as medicine in Usada. One of them comes from the Zingiberaceae family. The Zingiberaceae family is known as ginger plants with characteristics such as has rhizome, pseudo-stems, and single leaves. The characteristics of each genus and species of this family are its inflorescence that has a distinctive shape and colour. The rhizome of this family is used for medication because it contains aromatic compounds as a characteristic of each species in its use for local societies. Aromatic compounds are usually the result of secondary metabolites such as essential oils which contains a lot of benefits, for example as an antibacterial ${ }^{[3]}$.

Antibacterial compounds are able to kill or inhibit bacterial growth or 
metabolism. Based on its mechanism of action, it is divided into bacteriostatic and bactericidal. Bacteriostatic antibacterial is an antibacterial that in which able to inhibit bacterial growth and bactericidal is an antibacterial that able to kill bacteria ${ }^{[4]}$. According to Usada, plants from the Zingiberaceae family can be used to treat digestive, respiratory, and skin diseases which are generally caused by a bacterial infection. Therefore, the author wants to do a literature review about an antibacterial activity from the Zingiberaceae family and see its validity as a traditional use as antibacterial based on Balinese local wisdom medication method (Usada) with its scientific evidence.

\section{METHODS}

The articles used in this literature review were obtained through the internet with the keyword are "Aktivitas antibakteri tanaman Zingiberaceae" and "Antimicrobial activity of Zingiberaceae". After screening articles, 29 international articles and 23 national articles were obtained.

\section{RESULTS}

The Zingiberaceae family mentioned in Usada Bali such as Curcuma longa, Alpinia galanga, Zingiber cassumunar, Curcuma xanthorrhiza, Kaempferia galanga, Zingiber officinale, and Boesenbergia pandurata were used for traditional medication as antibacterial. The types of Usada, usage, and how to use are shown in Tables 1 and 2.

Based on several studies, the Zingiberaceae family mentioned in Usada Bali has an antibacterial activity which can be seen in tables 3, 4, and 5. One method that may be used to determine antibacterial activity is the diffusion method by measuring the inhibition zone due to categorizing the strength of the antibacterial activity of the compound.

\section{DISCUSSION}

Diffusion method was used to determine the antibacterial activity, which consists of a cylinder, well, and paper disc methods.

Table 1. Traditional medication from Curcuma longa, Curcuma xanthorrhiza, and Alpinia galanga based on Usada Bali

\begin{tabular}{|c|c|c|c|c|}
\hline Plant Species & Usada & Function & How to Use & References \\
\hline \multirow{5}{*}{ Curcuma longa } & $\begin{array}{l}\text { Usada Tenung } \\
\text { Tanyalara }\end{array}$ & $\begin{array}{c}\text { Asthma } \\
\text { Cough } \\
\text { Stomachache }\end{array}$ & Oral & [5] \\
\hline & Usada Upas & $\begin{array}{c}\text { Stomachache } \\
\text { Fever }\end{array}$ & $\begin{array}{c}\text { Topical } \\
\text { Oral }\end{array}$ & [6] \\
\hline & Usada Rare & $\begin{array}{c}\text { Cough } \\
\text { Diarrhea } \\
\text { Stomachache }\end{array}$ & Oral & [7] \\
\hline & $\begin{array}{c}\text { Usada Taru } \\
\text { Premana }\end{array}$ & $\begin{array}{c}\text { Cough } \\
\text { Diarrhea } \\
\text { Skin disease }\end{array}$ & $\begin{array}{l}\text { Topical } \\
\text { Oral } \\
\text { Topical }\end{array}$ & [8] \\
\hline & $\begin{array}{c}\text { Usada Tiwas } \\
\text { Punggung }\end{array}$ & Stomachache & Topical & [6] \\
\hline $\begin{array}{c}\text { Curcuma } \\
\text { xanthorrhiza }\end{array}$ & $\begin{array}{c}\text { Usada Tenung } \\
\text { Tanyalara } \\
\end{array}$ & $\begin{array}{c}\text { Fever } \\
\text { Stomachache }\end{array}$ & $\begin{array}{c}\text { Topical } \\
\text { Oral }\end{array}$ & {$[5]$} \\
\hline \multirow{4}{*}{ Alpinia galanga } & Usada Rare & $\begin{array}{c}\text { Fever } \\
\text { Skin disease }\end{array}$ & Topical & [7] \\
\hline & Usada Netra & Fever & Oral & [7] \\
\hline & $\begin{array}{l}\text { Usada Tenung } \\
\text { Tanyalara }\end{array}$ & $\begin{array}{l}\text { Skin disease } \\
\text { Stomachache }\end{array}$ & Topical & {$[5]$} \\
\hline & Usada Upas & $\begin{array}{c}\text { Stomachache } \\
\text { Cough }\end{array}$ & Oral & {$[6]$} \\
\hline
\end{tabular}


Table 2. Traditional medication from Zingiber cassumunar, Kaempferia galanga, Zingiber officinale, and Boesenbergia pandurata based on Usada Bali

\begin{tabular}{|c|c|c|c|c|}
\hline Plant Species & Usada & Function & How to Use & References \\
\hline \multirow{3}{*}{ Zingiber cassumunar } & Usada Netra & Stomachache & Topical & [7] \\
\hline & Usada Rare & Skin disease & Topical & [7] \\
\hline & Usada Upas & Stomachache & Topical & [6] \\
\hline \multirow{3}{*}{ Kaempferia galanga } & $\begin{array}{l}\text { Usada Tenung } \\
\text { Tanyalara }\end{array}$ & $\begin{array}{c}\text { Asthma } \\
\text { Fever }\end{array}$ & Oral & [5] \\
\hline & Usada Netra & $\begin{array}{c}\text { Nausea } \\
\text { Vomiting } \\
\text { Stomachache } \\
\text { Cough }\end{array}$ & Oral & [7] \\
\hline & Usada Upas & $\begin{array}{c}\text { Stomachache } \\
\text { Cough }\end{array}$ & Oral & [6] \\
\hline \multirow{4}{*}{ Zingiber officinale } & Usada Netra & Stomachache & Topical & [7] \\
\hline & Usada Rare & $\begin{array}{c}\text { Fever } \\
\text { Skin disease }\end{array}$ & Topical & [7] \\
\hline & $\begin{array}{c}\text { Usada Tenung } \\
\text { Tanyalara }\end{array}$ & $\begin{array}{l}\text { Fever } \\
\text { Cough }\end{array}$ & Oral & [5] \\
\hline & $\begin{array}{l}\text { Usada Tiwas } \\
\text { Punggung }\end{array}$ & Stomachache & Oral & [6] \\
\hline $\begin{array}{l}\text { Boesenbergia } \\
\text { pandurata }\end{array}$ & $\begin{array}{l}\text { Usada Tenung } \\
\text { Tanyalara }\end{array}$ & $\begin{array}{l}\text { Asthma } \\
\text { Cough }\end{array}$ & Oral & [5] \\
\hline
\end{tabular}

Table 3. Antibacterial activity from Curcuma longa and Curcuma xanthorrhiza

\begin{tabular}{|c|c|c|c|c|c|}
\hline Plant Species & $\begin{array}{l}\text { Chemical } \\
\text { Compounds }\end{array}$ & Bacterial Species & $\begin{array}{c}\text { Inhibition } \\
\text { Zone } \\
(\mathbf{m m})\end{array}$ & $\begin{array}{c}\text { Types of } \\
\text { Action }\end{array}$ & References \\
\hline \multirow{12}{*}{ Curcuma longa } & \multirow{12}{*}{$\begin{array}{l}\text { Alkaloids, } \\
\text { tannins, } \\
\text { flavonoids, } \\
\text { curcumin, and } \\
\text { essential oils }\end{array}$} & Escherichia coli & $5.64 \pm 0.25$ & Moderate & [9] \\
\hline & & Shigella dysentriae & 10.30 & Strong & [10] \\
\hline & & Salmonella thypi & 12.10 & Strong & [11] \\
\hline & & Escherichia coli & 7 & Moderate & [12] \\
\hline & & Bacillus cereus & $16.30 \pm 0.90$ & Strong & [13] \\
\hline & & Shigella dysentriae & 10 & Moderate & [14] \\
\hline & & $\begin{array}{c}\text { Staphylococcus } \\
\text { aureus }\end{array}$ & 12 & Strong & [15] \\
\hline & & $\begin{array}{c}\text { Staphylococcus } \\
\text { aureus }\end{array}$ & $28 \pm 1$ & Very Strong & [16] \\
\hline & & Bacillus subtilis & 13 & Strong & [17] \\
\hline & & Escherichia coli & 27 & Very Strong & [18] \\
\hline & & $\begin{array}{c}\text { Staphylococcus } \\
\text { aureus }\end{array}$ & 20 & Strong & [19] \\
\hline & & Bacillus cereus & 12 & Strong & [20] \\
\hline \multirow{6}{*}{$\begin{array}{c}\text { Curcuma } \\
\text { xanthorrhiza }\end{array}$} & \multirow{6}{*}{$\begin{array}{l}\text { Alkaloids, } \\
\text { flavonoids, } \\
\text { saponins, } \\
\text { curcumin, and } \\
\text { essential oils } \\
\text { (Xanthorrhizol) }\end{array}$} & $\begin{array}{l}\text { Escherichia coli } \\
\text { Salmonella thypi }\end{array}$ & $\begin{array}{c}3.94 \pm 0.01 \\
15.50\end{array}$ & $\begin{array}{l}\text { Weak } \\
\text { Strong }\end{array}$ & $\begin{array}{c}{[9]} \\
{[11]}\end{array}$ \\
\hline & & Bacillus cereus & $9.64 \pm 0.45$ & Moderate & [21] \\
\hline & & $\begin{array}{c}\text { Staphylococcus } \\
\text { aureus }\end{array}$ & 8 & Moderate & [22] \\
\hline & & Escherichia coli & $9.40 \pm 0.35$ & Moderate & [23] \\
\hline & & $\begin{array}{c}\text { Klebsiella } \\
\text { pneumoniae }\end{array}$ & $9.68 \pm 0.58$ & Moderate & [24] \\
\hline & & $\begin{array}{l}\text { Streptococcus } \\
\text { mutans }\end{array}$ & 4 & Weak & [25] \\
\hline
\end{tabular}


Table 4. Antibacterial activity from Alpinia galanga, Zingiber cassumunar, and Kaempferia galanga

\begin{tabular}{|c|c|c|c|c|c|}
\hline Plant Species & $\begin{array}{l}\text { Chemical } \\
\text { Compounds }\end{array}$ & Bacterial Species & $\begin{array}{c}\text { Inhibition Zone } \\
(\mathbf{m m})\end{array}$ & $\begin{array}{l}\text { Types of } \\
\text { Action }\end{array}$ & References \\
\hline \multirow{9}{*}{ Alpinia galanga } & \multirow{9}{*}{$\begin{array}{l}\text { Alkaloids, } \\
\text { flavonoids, } \\
\text { saponins, and } \\
\text { essential oils }\end{array}$} & Escherichia coli & 7 & Moderate & {$[26]$} \\
\hline & & Bacillus subtilis & $16 \pm 4.60$ & Strong & [27] \\
\hline & & $\begin{array}{c}\text { Staphylococcus } \\
\text { aureus }\end{array}$ & $27.21 \pm 0.21$ & Very Strong & [28] \\
\hline & & Escherichia coli & 10.34 & Strong & [29] \\
\hline & & Bacillus cereus & $11.80 \pm 2.80$ & Moderate & [13] \\
\hline & & Bacillus cereus & 10.30 & Strong & [30] \\
\hline & & $\begin{array}{c}\text { Staphylococcus } \\
\text { aureus }\end{array}$ & $16.67 \pm 1.15$ & Strong & [31] \\
\hline & & $\begin{array}{c}\text { Staphylococcus } \\
\text { aureus }\end{array}$ & $22.33 \pm 0.58$ & Very Strong & {$[32]$} \\
\hline & & Bacillus cereus & 13 & Strong & [20] \\
\hline \multirow{6}{*}{$\begin{array}{c}\text { Zingiber } \\
\text { cassumunar }\end{array}$} & \multirow{6}{*}{$\begin{array}{l}\text { Alkaloids, } \\
\text { flavonoids, } \\
\text { saponins, } \\
\text { tannins, and } \\
\text { essential oils }\end{array}$} & Escherichia coli & 7.50 & Moderate & [33] \\
\hline & & $\begin{array}{c}\text { Staphylococcus } \\
\text { aureus }\end{array}$ & $11.33 \pm 0.57$ & Strong & [34] \\
\hline & & Bacillus cereus & 12.76 & Strong & [35] \\
\hline & & Salmonella thypi & 8 & Moderate & [36] \\
\hline & & $\begin{array}{c}\text { Staphylococcus } \\
\text { aureus }\end{array}$ & $16.68 \pm 2.78$ & Strong & [37] \\
\hline & & Escherichia coli & 6.93 & Moderate & [38] \\
\hline \multirow{8}{*}{$\begin{array}{l}\text { Kaempferia } \\
\text { galanga }\end{array}$} & \multirow{8}{*}{$\begin{array}{l}\text { Flavonoids, } \\
\text { phenols (ethyl } \\
\text { p-methoxy } \\
\text { cinnamate), } \\
\text { tannins, } \\
\text { saponins, and } \\
\text { essential oils }\end{array}$} & Escherichia coli & 18.33 & Strong & [39] \\
\hline & & Bacillus subtilis & 8.66 & Moderate & [40] \\
\hline & & $\begin{array}{c}\text { Staphylococcus } \\
\text { aureus }\end{array}$ & 12 & Strong & [41] \\
\hline & & $\begin{array}{l}\text { Porphyromonas } \\
\text { gingivalis }\end{array}$ & $18.87 \pm 1.99$ & Strong & [42] \\
\hline & & Escherichia coli & $9.80 \pm 1.60$ & Moderate & [43] \\
\hline & & $\begin{array}{c}\text { Staphylococcus } \\
\text { aureus }\end{array}$ & 11 & Strong & [44] \\
\hline & & Bacillus cereus & $10 \pm 0.41$ & Moderate & {$[45]$} \\
\hline & & $\begin{array}{c}\text { Staphylococcus } \\
\text { aureus }\end{array}$ & 11 & Strong & {$[31]$} \\
\hline
\end{tabular}

The cylinder method is a method that place a several-cylinder glass or stainless steel on the bacteria inoculated media. Each cylinder place to stand on the media and filled with the tested solution then incubated. Furthermore, bacterial growth will observe by measuring the inhibition zone around the cylinder. The well method is to make wells on the bacteria inoculated media. It adjusted with the number and position of wells due to the research objective. Each of well is filled by the tested solution then incubated. Right after, the bacterial growth will observe by measuring the inhibition zone around the well. The paper disc method is to soak a paper disc in the tested solution and placed on the bacteria inoculated media. Furthermore, bacterial growth will observe by measuring the inhibition zone around the paper disc ${ }^{[61]}$.

The strength of antibacterial activity from a compound can be seen from a diameter of the inhibition formed zone. Bigger diameter shows the stronger antibacterial activity. The category of antibacterial activity based on the diameter of the inhibitory zone consist of four types of action $^{[62]}$.

Based on tables 3, 4, and 5, the results of studies from the Zingiberaceae family can be categorized according to the level of its antibacterial activity. Curcuma longa has antibacterial activity with moderate, strong, and very strong responses. 
Tabel 5. Antibacterial activity from Zingiber officinale and Boesenbergia pandurata

\begin{tabular}{|c|c|c|c|c|c|}
\hline Plant Species & $\begin{array}{l}\text { Chemical } \\
\text { Compounds }\end{array}$ & Bacterial Species & $\begin{array}{c}\text { Inhibition } \\
\text { Zone } \\
(\mathbf{m m})\end{array}$ & $\begin{array}{l}\text { Types of } \\
\text { Action }\end{array}$ & References \\
\hline \multirow{13}{*}{$\begin{array}{l}\text { Zingiber } \\
\text { officinale }\end{array}$} & \multirow{13}{*}{$\begin{array}{l}\text { Flavonoids, } \\
\text { phenols, } \\
\text { saponins, and } \\
\text { essential oils. }\end{array}$} & Escherichia coli & 18 & Strong & [46] \\
\hline & & $\begin{array}{c}\text { Staphylococcus } \\
\text { aureus }\end{array}$ & 6 & Moderate & [47] \\
\hline & & Bacillus subtilis & $13.60 \pm 0.27$ & Strong & [48] \\
\hline & & Escherichia coli & $12.50 \pm 1.20$ & Strong & [13] \\
\hline & & Salmonella thypi & 20 & Strong & [18] \\
\hline & & $\begin{array}{c}\text { Staphylococcus } \\
\text { aureus }\end{array}$ & 16 & Strong & [20] \\
\hline & & Escherichia coli & 10.56 & Strong & [49] \\
\hline & & $\begin{array}{l}\text { Salmonella } \\
\text { thypimurium }\end{array}$ & 8 & Moderate & [50] \\
\hline & & Bacillus subtilis & $6.05 \pm 0.05$ & Moderate & [51] \\
\hline & & $\begin{array}{l}\text { Streptococcus } \\
\text { mutans }\end{array}$ & 6 & Moderate & [25] \\
\hline & & $\begin{array}{c}\text { Staphylococcus } \\
\text { aureus }\end{array}$ & $10.30 \pm 0.07$ & Strong & {$[52]$} \\
\hline & & Bacillus cereus & $10.33 \pm 0.76$ & Moderate & [53] \\
\hline & & $\begin{array}{l}\text { Aggregatibacter } \\
\text { actinomycetem- } \\
\text { comitans }\end{array}$ & 11.10 & Strong & [54] \\
\hline \multirow{7}{*}{$\begin{array}{c}\text { Boesenbergia } \\
\text { pandurata }\end{array}$} & \multirow{7}{*}{$\begin{array}{c}\text { Essential oils } \\
\text { (1,8-cineol, } \\
\text { geraniol) }\end{array}$} & Bacillus cereus & 14 & Strong & [20] \\
\hline & & $\begin{array}{c}\text { Streptococcus } \\
\text { mutans }\end{array}$ & 6.70 & Moderate & [55] \\
\hline & & $\begin{array}{c}\text { Streptococcus } \\
\text { mutans }\end{array}$ & $10.46 \pm 0.29$ & Strong & [56] \\
\hline & & $\begin{array}{l}\text { Streptococcus } \\
\text { mutans }\end{array}$ & 1.85 & Weak & [57] \\
\hline & & $\begin{array}{c}\text { Pseudomonas } \\
\text { aeruginosa }\end{array}$ & 13.85 & Strong & [58] \\
\hline & & $\begin{array}{c}\text { Staphylococcus } \\
\text { aureus }\end{array}$ & 13.60 & Strong & [59] \\
\hline & & $\begin{array}{l}\text { Streptococcus } \\
\text { pyogenes }\end{array}$ & 7 & Moderate & [60] \\
\hline
\end{tabular}

Curcuma xanthorrhiza has antibacterial activity with weak, moderate, and strong responses. Alpinia galanga has antibacterial activity with moderate, strong, and very strong responses.

Table 6. Category of antibacterial activity $^{[62]}$

$\begin{array}{cc}\text { Type of Action } & \text { Inhibition Zone (mm) } \\ \text { Weak } & <5 \\ \text { Moderate } & 5-10 \\ \text { Strong } & 10-20 \\ \text { Very Strong } & >20\end{array}$

Zingiber cassumunar has antibacterial activity with moderate and strong responses. Kaempferia galanga has antibacterial activity with moderate and strong responses. Zingiber officinale has antibacterial activity with moderate and strong responses. Boesenbergia pandurata has antibacterial activity with weak, moderate, and strong responses. The difference in antibacterial activity caused by the type of bacteria that was inhibited which can be seen in table 7 .

The result of literature studies from several research journals showed that the type of bacteria that was inhibited by compounds in the Zingiberaceae family are bacteria that cause digestive, respiratory, and skin infections so that shows the validity between traditional use from the Zingiberaceae family as an antibacterial 
based on Balinese local wisdom medication method (Usada) with its scientific evidence.

Table 7. The type of bacteria that was inhibited by Zingiber Bacterial Species Types of Diseases

\begin{tabular}{|c|c|}
\hline \multirow{2}{*}{\multicolumn{2}{|c|}{ Gram-Positive Bacteria }} \\
\hline & \\
\hline Bacillus cereus & Diarrhea \\
\hline b. Bacillus subtilis & Diarrhea \\
\hline $\begin{array}{l}\text { c. Staphylococcus } \\
\text { aureus }\end{array}$ & Diarrhea \\
\hline $\begin{array}{l}\text { d. Streptococcus } \\
\text { mutans }\end{array}$ & Dental decay \\
\hline $\begin{array}{l}\text { e. } \begin{array}{l}\text { Streptococcus } \\
\text { pyogenes }\end{array} \\
\end{array}$ & $\begin{array}{l}\text { Throat and skin } \\
\text { infections }\end{array}$ \\
\hline \multicolumn{2}{|c|}{ Gram-Negative Bacteria } \\
\hline $\begin{array}{l}\text { a. Aggregatibacter } \\
\text { actinomycetem } \\
\text { comitans }\end{array}$ & Periodontal diseases \\
\hline b. Escherichia coli & Diarrhea \\
\hline c. Shigella dysentriae & Diarrhea \\
\hline d. Salmonella thypi & Salmonellosis \\
\hline $\begin{array}{l}\text { e. Salmonella } \\
\text { thypimurium }\end{array}$ & Salmonellosis \\
\hline $\begin{array}{ll}\text { f. } & \text { Klebsiella } \\
\text { pneumoniae }\end{array}$ & $\begin{array}{l}\text { Respiratory trac } \\
\text { infection }\end{array}$ \\
\hline $\begin{array}{l}\text { g. Porphyromonas } \\
\text { gingivalis }\end{array}$ & Periodontal diseases \\
\hline $\begin{array}{l}\text { h. } \begin{array}{l}\text { Pseudomonas } \\
\text { aeruginosa }\end{array}\end{array}$ & Skin infection \\
\hline
\end{tabular}

Gram-positive bacteria and gramnegative bacteria have different cell wall structures that affect their sensitivity to antibacterial. The difference is in the content of peptidoglycan and lipids from gram-positive and gram-negative bacteria. Gram-positive bacteria contain approximately $70 \%$ of peptidoglycan from the dry mass of cell wall which causes the cell wall thick and stiff and gram-negative bacteria contain approximately $10 \%$ of peptidoglycan from the dry mass of cell wall which causes the cell wall thinner. Moreover, gram-negative bacteria have porin proteins and high lipid levels. Porin proteins act as a pathway for the entry of active substances into bacterial cells. Active substances in the bacterial cell can damage the enzyme activity in the cell and causing cell damage. Meanwhile, high lipid levels in the bacterial cells potentially increase the permeability of active substances into cells $^{[23]}$.

The antibacterial activity of the Zingiberaceae family is caused by its secondary metabolites, such as alkaloids, flavonoids, polyphenols, saponins, tannins, and essential oils ${ }^{[23]}$. Each of compound has different inhibition mechanism. In general, the mechanism of antibacterial action compound is based on the bacterial structure and composition, such as an enzyme, nucleic acid, cytoplasmic membrane, and cell wall. If one of the structures and composition damage, it will be the beginning of the changes that cause cell death.

Essential oils act as antibacterial because they contain hydroxyl and carbonyl functional groups which are derivatives of phenol. Phenol derivatives will interact with bacterial cell walls, then absorbed and penetrated bacterial cells. This will cause the precipitation and denaturation of proteins that can lyse the bacterial cell membrane ${ }^{[10]}$. Xanthorrhizol is an active compound from Curcuma xanthorrhiza essential oils that can affect cell wall morphology by attacking cell membrane, nucleic acid, and bacterial metabolism ${ }^{[23]}$. Curcumin is an active compound from Curcuma longa rhizome which is polyphenols compound. Curcumin acts as an antibacterial by inhibiting the proliferation of bacterial cells ${ }^{[10]}$. Alkaloids and flavonoids act as antibacterial by denaturing protein and then damage the bacterial cell wall. Saponins act as antibacterial by disturbing permeability of bacterial cell wall ${ }^{[54]}$. Meanwhile, tannins act as antibacterial by damaging the bacterial cell membrane ${ }^{[23]}$.

\section{CONCLUSION}

Based on the result of several studies shows the Zingiberaceae family mentioned in Usada Bali to treat digestive, respiratory, and skin diseases have been scientifically proved to have antibacterial activity with various inhibitions from weak to very 
strong depended on the type of bacteria. So, it shows the validity as a traditional use as antibacterial based on Balinese local wisdom medication method (Usada) with its scientific evidence.

\section{CONFLICT OF INTEREST}

No conflict of interest in this paper. This paper was written independently without being affiliated by another party.

\section{ACKNOWLEDGMENT}

We would like to thank the lecturers and staff in the Department of Pharmacy, Faculty of Math and Science, Udayana University, for the support in the implementation of this review.

\section{REFERENCES}

1. Daniah. Kearifan Lokal (Local Wisdom) Sebagai Basis Pendidikan Karakter. PIONIR: Jurnal Pendidikan. 2016; 5(2):1-14.

2. Mu'jizah. Naskah Usada Sebagai Kearifan Lokal Masyarakat Bali. DIALEKTIKA: Jurnal Bahasa, Sastra, dan Pendidikan Bahasa dan Sastra Indonesia. 2016; 3(2):191-200.

3. Hartanto, S., Fitmawati, dan N. Sofiyanti. Studi Etnobotani Famili Zingiberaceae dalam Kehidupan Masyarakat Lokal di Kecamatan Pangean Kabupaten Kuantan Singingi, Riau. Biosaintifika: Journal of Biology \& Biology Education. 2014; 6(2):122132.

4. Trisia, A., R. Philyria, dan A. N. Toemon. Uji Aktivitas Antibakteri Ekstrak Etanol Daun Kalanduyung (Guasuma ulmifolia Lam.) Terhadap Pertumbuhan Staphylococcus aureus dengan Metode Difusi Cakram (KirbyBauer). Anterior Jurnal. 2018; 17(2):136-143.

5. Sudiasta, I. G. B. dan Suwidja, I. K. Terjemahan dan Kajian Usada Tenung Tanya Lara. Jakarta: Direktorat Jenderal Kebudayaan; 1991.
6. Pulasari, J. M. Nawa Usadha Bali. Surabaya: Paramita; 2009.

7. Dinas Kesehatan Provinsi Bali. Himpunan Usadha. Edisi I. Denpasar: UPTD B POT KOM Dinas Kesehatan Provinsi Bali; 2008.

8. Putra, I. G. S. Taru Premana Khasiat Tanam-tanaman untuk Obat Tradisional. Denpasar: Penerbit PT. Upada Sastra; 1999.

9. Rahmawati, N., E. Sudjarwo, dan E. Widodo. Uji Aktivitas Antibakteri Ekstrak Herbal Terhadap Bakteri Escherichia coli. Jurnal Ilmu-Ilmu Peternakan. 2014; 24(3):24-31.

10. Yuliati. Uji Efektivitas Ekstrak Kunyit Sebagai Antibakteri Dalam Pertumbuhan Bacillus sp. dan Shigella dysentriae Secara In Vitro. Jurnal Profesi Medika. 2016; 10(1):26-32.

11. Retnaningsih, A. Uji Daya Hambat Rimpang Kunyit (Curcuma domestica Val) dan Rimpang Temulawak (Curcuma xanthorrhiza Roxb) Terhadap Bakteri Salmonella thypi. Jurnal Kesehatan Holistik. 2015; (3):158-160.

12. Arirahmayanti, I. G. A. E., I. G. A. Artini, dan D. K. Ernawati. Perbandingan Aktivitas Antibakteri Ekstrak Etanol Kunyit (Curcuma longa) dan Bawang Putih (Allium sativum) Terhadap Escherichia coli ATCC 8739. Jurnal Medika Udayana. 2019; 8(11).

13. Sunilson, J. A. J., R. Suraj, G. Rejitha, and K. Anandarajagopal. In Vitro Antimicrobial Evaluation of Zingiber officinale, Curcuma longa, and Alpinia galanga Extract as Natural Food Preservatives. American Journal of Food Technology. 2009; 4(5):1-8.

14. Khan, M. B., M. A. Rabby, M. H. Ullah, and C. F. Hossain. Investigation of Antimicrobial and Anti-Inflammatory Activity of Curcuma longa. International Journal of Pharmaceutical Sciences and Research. 2013; 4(3):1105-1109. 
15. Gupta, A., S. Mahajan, and R. Sharma. Evaluation of Antimicrobial Activity of Curcuma longa Rhizome Extract Against Staphylococcus aureus. Biotechnology Reports. 2015; 6:51-55.

16. Singh, S., B. S. S. Rajesh, K. Sahoo, E. Subudhi, and S. Nayak. Chemical Composition of Turmeric Oil (Curcuma longa L. cv. Roma) and Its Antimicrobial Activity Against Eye Infecting Pathogens. Journal of Essential Oil Research. 2011; 23(6):1118.

17. Harit, J., A. Barapatre, M. Prajapati, K. R. Aadil, and S. Senapati. Antimicrobial Activity of Rhizome of Selected Curcuma Variety. International Journal of Life Sciences Biotechnology and Pharma Research. 2013; 2(3):183-189.

18. Srinivasan, D., S. Nathan, T. Suresh, and P. L. Perumalsamy. Antimicrobial Activity of Certain Indian Medicinal Plants Used in Folkloric Medicine. Journal of Ethnopharmacology. 2001; 74(3):217-220.

19. Chen, I. N., C. C. Chang, C. C. Ng, C. Y. Wang, Y. T. Shyu, and T. L. Chang. Antioxidant and Antimicrobial Activity of Zingiberaceae Plants in Taiwan. Plants Food for Human Nutrition. 2008; 63(1):15-20.

20. Norajit, K., N. Laohakunjit, and O. Kerdchoechuen. Antibacterial Effect of Five Zingiberaceae Essential Oils. Molecules. 2007; 12(8):2047-2060.

21. Akarchariya, N., S. Sirilun, J. Julsrivigal, and S. Chansakaowa. Chemical Profiling and Antimicrobial Activity of Essential Oil from Curcuma aeruginosa Roxb., Curcuma glans K. Larsen \& J. Mood and Curcuma cf. xanthorrhiza Roxb. Collected in Thailand. Asian Pasific Journal of Tropical Biomedicine. 2017; 7(10):881885.

22. Mashita, A. R. Efek Antimikroba Ekstrak Rimpang Temulawak (Curcuma xanthorrhiza) Terhadap
Pertumbuhan Staphylococcus aureus. Saintika Medika. 2014; 10(2):138-144.

23. Purnamaningsih, N. A., H. Kalor, dan S. Atun. Uji Aktivitas Antibakteri Ekstrak Temulawak (Curcuma xanthorrhiza) Terhadap Bakteri Escherichia coli ATCC 11229 dan Staphylococcus aureus ATCC 25923. Jurnal Penelitian Saintek. 2017; 22(2):140-147.

24. Sylvester, W. S., R. Son, K. F. Liew, and Y. Rukayadi. Antibacterial Activity of Java Turmeric (Curcuma xanthorrhiza Roxb.) Extract Against Klebsiella pneumoniae Isolated from Several Vegetables. International Food Research Journal. 2015; 22(5):17701776.

25. Hertiani, T., S. U. T. Pratiwi, I. D. K. Irianto, D. Adityaningrum, and B. Pranoto. Pengaruh Minyak Atsiri dari Beberapa Tanaman Obat Indonesia Terhadap Biofilm Streptococcus mutans. Majalah Farmasi Indonesia. 2011; 22(3):174-181.

26. Parwata, I. M. O. dan P. F. S. Dewi. Isolasi dan Uji Aktivitas Antibakteri Minyak Atsiri dari Rimpang Lengkuas (Alpinia galangal L.). Jurnal Kimia. 2008; 2(2):100-104.

27. Amelia, R., Sudarso, dan D. Hartanti. Aktivitas Antibakteri Gel Ekstrak Lengkuas (Alpinia galanga) Terhadap Pseudomonas aeruginosa dan Bacillus subtilis. Pharmacy. 2010; 7(3):78-83.

28. Rao, K., B. Ch, L. M. Narasu, and A. Giri. Antibacterial Activity of Alpinia galanga (L) Willd Crude Extracts. Applied Biochemistry and Biotechnology. 2010; 162(3):871-884.

29. Kapitan, L. A. V. Aktivitas Antimikroba Ekstrak Laos Putih (Alpinia galangas) Terhadap Bakteri Escherichia coli dan Salmonella sp. Jurnal Info Kesehatan. 2017; 15(1):1519.

30. Wong, L. F., Y. Y. Lim, and M. Omar. Antioxidant and Antimicrobial Activities of Some Alpinia Species. 
Journal of Food Biochemistry. 2009; 33(6):835-851.

31. Sani, S. A., A. A. M. Faik, R. Abdulla, and S. Kunasekaran. Phytochemical, Antioxidant, and Antibacterial Activities of Two Kinds of Sabah Zingiberaceae. Journal of Physics: Conference Series. 2019; 1358:1-10.

32. Oonmetta-aree, J., T. Suzuki, P. Gasaluck, and G. Eumkeb. Antimicrobial Properties and Action of Galangal (Alpinia galangal Linn.) on Staphylococcus aureus. LWT - Food Science and Technology. 2006; 39(10):1214-1220.

33. Kamazeri, T. S. A. T., O. A. Samah, M. Taher, D. Susanti, and H. Qaralleh. Antimicrobial Activity and Essentian Oils of Curcuma aeruginosa, Curcuma manga, and Zingiber cassumunar from Malaysia. Asian Pasific Journal of Tropical Medicine. 2012; 5(3):202-209.

34. Boonyanugomol, W., K. Kraisriwattana, K. Rukseree, K. Boonsam, and P. Narachai. In Vitro Synergistic Antibacterial Activity of The Essential Oil from Zingiber cassumunar Roxb Against Extensively Drug-Resistant Acinetobacter baumannii Strains. Journal of Infection and Public Health. 2017; 10(5):586592.

35. Risnawati, E., A. Ainurofiq, and M. W. Wartono. Study of Antibacterial Activity and Identification of The Most Active Fraction from Ethanol Extraction of Zingiber cassumunar Roxb. Rhizomes by Vacuum Liquid Chromatography. Journal of Chemical and Pharmaceutical Research. 2014; 6(9):101-107.

36. Kusuma, I. W., H. Kuspradini, E. T. Arung, F. Aryani, Y. H. Min, J. S. Kim, and Y. U. Kim. Biological Activity and Phytochemical Analysis of Three Indonesian Medicinal Plants, Murraya koenigii, Syzygium polyanthum, and Zingiber purpurea. Journal of
Acupuncture and Meridian Studies. 2011; 4(1):75-79.

37. Taechowisan, $\quad$ T., $\quad$ S. Suttichokthanakorn, W. S. Phutdhawong. Antibacterial and Cytotoxicity Activities of Phenylbutanoids from Zingiber cassumunar Roxb. Journal of Applied Pharmaceutical Science. 2018; 8(07):121-127.

38. Wulandari, D., D. F. Ayu, dan A. Ali. Pengaruh Minyak Atsiri Bangle (Zingiber purpureum Roxb.) Sebagai Antibakteri Terhadap Kualitas Sabun Cair. Journal Agroindustri Halal. 2018; 4(1):001-009.

39. Fajeriyati, N. dan Andika. Uji Aktivitas Antibakteri Ekstrak Etanol Rimpang Kencur (Kaempferia galanga L.) Pada Bakteri Bacillus subtilis dan Escherichia coli. Journal of Current Pharmaceutical Sciences. 2017; 1(1):36-41.

40. Nugraha, S. A., K. Siadi, dan Sudarmin. Uji Antimikroba Etil-p-Metoksi Sinamat dari Rimpang Kencur Terhadap Bacillus subtilis. Indonesian Journal of Chemical Science. 2012; 1(2):147-151.

41. Tewtrakul, S., S. Yuenyongsawad, S. Kummee, and L. Atsawajaruwan. Chemical Components and Biological Activities of Volatile Oil of Kaempferia galanga Linn. Songklanakarin Journal of Science and Technology. 2005; 27(2):503-507.

42. Nanasombat, S., N. Kuncharoen, B. Ritcharoon, and P. Sukcharoen. Antibacterial Activity of Thai Medicinal Plant Extracts Against Oral and Gastrointestinal Pathogenic Bacterial and Prebiotic Effect on The Growth of Lactobacillus acidophilus. Chiang Mai Journal of Science. 2018; 45(1):33-44.

43. Fahrinda, A., S. Ismail, K. Kosala, I. Fikriah, and Yuniati. Evaluation of Synergistic Effect of Kaempferia galanga L. Rhizome Extracts with 
Antibiotics Against Bacterial

Pathogens. Journal of Tropical Pharmacy and Chemistry. 2018; 4(3):108-113.

44. Haerazi, A., D. S. D. Jekti, dan Y. Andayani. Uji Aktivitas Antibakteri Ekstrak Kencur (Kaempferia galanga L.) Terhadap Pertumbuhan Bakteri Staphylococcus aureus dan Streptococcus viridans. Jurnal Ilmiah Biologi "Bioscientist". 2014; 2(1):1-11.

45. Dash, P. R., M. Nasrin, and M. S. Ali. In Vivo Cytotoxic and In Vitro Antibacterial Activities of Kaempferia galanga. Journal of Pharmacognosy and Phytochemistry. 2014; 3(1):172177.

46. Indu, M. N., A. A. M. Hatha, C. Abirosh, U. Harsha, and G. Vivekanandan. Antimicrobial Activity of Some of The South-Indian Spices Against Serotypes of Escherichia coli, Salmonella, Listeria monocytogenes, and Aeromonas hydrophila. Brazilian Journal of Microbiology. 2006; 37(2):153-158.

47. Akoachere, J. F. T. K, R. N. Ndip, E. B. Chenwi, L. M. Ndip, T. E. Njock, and D. N. Anong. Antibacterial Effect of Zingiber officinale and Garcinia kola on Respiratory Tract Pathogens. East African Medical Journal. 2002; 79(11):588-592.

48. Gull, I., M. Saeed, H. Shaukat, S. M. Aslam, Z. Q. Samra, and A. M. Athar. Inhibitory Effect of Allium sativum and Zingiber officinale Extracts on Clinically Important Drug Resistant Pathogenic Bacteria. Annals of Clinical Microbiology and Antimicrobials. 2012; 11(1):1-6.

49. Ali, S., M. Baharuddin, dan Sappewali. Pengujian Aktivitas Antibakteri Minyak Atsiri Jahe (Zingiber officinale Roscoe) Terhadap Bakteri Staphylococcus aureus dan Escherichia coli. Al-Kimia. 2013; 1(2):18-31.

50. Mursalim, M. F. dan A. W. Jamaluddin. Aktivitas Antimikroba Kombinasi
Ekstrak Propolis Trigona sp. dan Jahe (Zingiber officinale Roscoe) Terhadap Bakteri Salmonella thypimurium. AsSyifaa Jurnal Farmasi. 2019; 11(01):70-74.

51. Sasidharan, I. dan A. N. Menon. Comparative Chemical Composition and Antimicrobial Activity Fresh \& Dry Ginger Oils (Zingiber officinale Roscoe). International Journal of Current Pharmaceutical Research. 2010; 2(4):40-43.

52. Lely, N., A. Firdiawan, dan S. Martha. Efektivitas Antibakteri Minyak Atsiri Rimpang Jahe Merah (Zingiber officinale var. Rubrum) Terhadap Bakteri Jerawat. Scientia Jurnal Farmasi dan Kesehatan. 2016; 6(1):4449.

53. Rialita, T., W. P. Rahayu, L. Nuraida, dan B. Nurtama. Aktivitas Antimikroba Minyak Esensial Jahe Merah (Zingiber officinale var. Rubrum) dan Lengkuas Merah (Alpinia purpurata K. Schum) Terhadap Bakteri Patogen dan Perusak Pangan. Agritech. 2015; 35(1):43-52.

54. Saptiwi, B., L. Sunarjo, dan H. Rahmawati. Perasan Jahe Merah (Zingiber officinale Var. Rubrum) Terhadap Daya Hambat Bakteri Aggregatibacter

actinomycetemcomitans. Jurnal Riset Kesehatan. 2018; 7(2):61-65.

55. Mahmudah, F. L. dan S. Atun. Uji Aktivitas Antibakteri dari Ekstrak Etanol Temu Kunci (Boesenbergia pandurata) Terhadap Bakteri Streptococcus mutans. Jurnal Penelitian Saintek. 2017; 22(1):59-66.

56. Taweechaisupapong, S., S. Singhara, P. Lertsatitthanakorn, and W. Khunkitti. Antimicrobial Effects of Boesenbergia pandurata and Piper sarmentosum Leaf Extracts on Planktonic Cells and Biofilm of Oral Pathogens. Pakistan Journal of Pharmaceutical Sciences. 2010; 23(2):224-231.

57. Handayani, S., S. Mursiti, dan N. Wijayati. Uji Aktivitas Antibakteri 
Senyawa Flavonoid dari Rimpang Temu Kunci (Kaempferia pandurata Roxb.) Terhadap Streptococcus mutans. Indonesian Journal of Chemical Science. 2018; 7(2):146-152.

58. Girsang, F. M., T. Armansyah, M. Abrar, Erina, Darniati, dan Nuzul Asmilia. Effect of Temu Kunci's Root (Boesenbergia pandurata) Extract to Pseudomonas aeruginosa. Jurnal Medika Veterinaria. 2019; 13(2):166171.

59. Keliat, S. P. N., Darniati, A. Harris, Erina, Rinidar, dan Fahkrurrazi. The Effect of Fingerroot Rhizome (Boesenbergia pandurata) Extract on The Growth of Staphylococcus aureus In Vitro. Jurnal Medika Veterinaria. 2019; 13(2):178-184.

60. Limsuwan, S. dan S. P. Voravuthikunchai. Anti-Streptococcus pyogenes Activity of Selected Medicinal Plant Extracts Used in Thai Traditional Medicine. Tropical Journal of Pharmaceutical Research. 2013; 12(4):535-540.

61. Kusmiyati dan N. W. S. Agustini. Uji Aktivitas Senyawa Antibakteri dari Mikroalga Porphyridium cruentum. BIODIVERSITAS. 2007; 8(1):48-53.

62. Davis, W. W. and T. R. Stout. Disc Plate Methods of Microbiological Antibiotic Assay. Microbiology. 1971; 22:659665. 